\title{
Bacteriocinogenic Lactococcus lactis subsp. lactis DF04Mi isolated from goat milk: Evaluation of the probiotic potential
}

\author{
Danielle N. Furtado, Svetoslav D. Todorov, Mariza Landgraf, Maria T. Destro, \\ Bernadette D.G.M. Franco
}

Laboratório de Microbiologia de Alimentos, Departamento de Alimentos e Nutrição Experimental, Faculdade de Ciências Farmacêuticas, Universidade de São Paulo, São Paulo, SP, Brazil.

Submitted: July 12, 2013; Approved: March 14, 2014.

\begin{abstract}
Lactic acid bacteria capable of producing bacteriocins and presenting probiotic potential open innovative technological applications in the dairy industry. In this study, a bacteriocinogenic strain (Lactococcus lactis subsp. lactis DF4Mi) was isolated from goat milk, and studied for its probiotic potential. Lc. lactis DF4Mi was resistant to acidic $\mathrm{pH}$ and oxbile, presented co-aggregation with Listeria monocytogenes, and was not affected by several drugs from different generic groups, being sensitive to most tested antibiotics. These properties indicate that this Lc. lactis strain can be used for enhancement of dairy foods safety and quality, in combination with potential probiotic properties.
\end{abstract}

Key words: bacteriocin, probiotic, Lc. lactis subsp. lactis, biopreservation, goat milk.

\section{Introduction}

Lactic acid bacteria (LAB) present many important properties in food manufacturing, such as improvement of organoleptic and physical characteristics, production of lactic acid contributing to the extension of the shelf life, and reduction of lactose content. Several LAB are used in dairy industries as starter cultures as well as probiotics. Probiotics are defined as live microorganisms which when administered in adequate amounts confer health benefits to the host (WHO, 2002; Bertazonni-Minelli et al., 2004; Oelschaeger, 2010; Todorov et al., 2012). Probiotic beneficial effect for the host include suppression of growth of pathogens, control of serum cholesterol level, modulation of the immune system, improvement of lactose digestion, synthesis of vitamins, increase in bio-availability of minerals and possible anti-carcinogenic activity (Gomes and Xavier, 1999; Kailasapathy and Chin, 2000; Chan and Zhang, 2005). Bacteriocin producing LAB may also present a probiotic potential if capable of surviving the harsh conditions in the gastro-intestinal tract (GIT), including low $\mathrm{pH}$ and high concentrations of bile salts. As probiotics, these bacteria can confer health benefits to the host such as reduction of gastrointestinal infections and inflammatory bowel disease, modulation of the immune system, and defense against colonization by pathogenic microorganisms (WHO, 2002; Galdeano et al., 2007; Oelschlaeger, 2010).

Aggregation of LAB is an important feature in evaluation of potential probiotic properties. While auto-aggregation may result in biofilm formation, co-aggregation with pathogens is important for elimination of non-desirable strains from the GIT (Todorov and Dicks, 2008). These capabilities are strain-specific and depend on species-specific surface proteins that recognize or bind to components in the environment. According to Kleerebezem et al. (2003), several genes encoding for surface proteins are homologous to genes coding for proteins with predicted functions, such as mucus-binding, aggregation-promotion and intracellular adhesion.

In the evaluation of a possible probiotic potential of LAB it is important to check for antibiotic resistance as they can act as potential reservoirs of resistance genes that can be transferred to other microorganisms, producing multidrug resistant strains (Dicks et al., 2011). Probiotic consumers may be under treatment for a variety of illnesses, and the beneficial effects of the probiotic strain may be hampered by possible interactions with the medicaments used by these consumers. It should be emphasized that the

Send correspondence to S.D. Todorov. Laboratório de Microbiologia de Alimentos, Departamento de Alimentos e Nutrição Experimental, Faculdade de Ciências Farmacêuticas, Universidade de São Paulo, Av. Prof. Lineu Prestes 580, 05508-000 São Paulo, SP, Brazil. E-mail: slavi310570@abv.bg. 
interaction between antibiotics or other medicaments and probiotic bacteria in the GIT depends on their concentration in this environment (Todorov et al., 2007; Todorov et al., 2008), so establishing the Minimal Inhibitory Concentration (MIC) values play an important role for the proper evaluation of these interactions. Of higher importance are the drugs for treatment of chronic diseases normally used in long course treatments, since they may accumulate in the gastrointestinal tract and affect the viability of probiotic bacteria (Carvalho et al., 2009).

Application of bacteriocinogenic strains for dairy product preservation is in agreement with consumers' demands for foods that are naturally preserved. Additional claims of health-promoting benefits due to probiotic activity bring extra value to these foods. In this study we report results on the evaluation of the probiotic potential of the strain Lc. lactis DF04Mi.

\section{Materials and Methods}

\section{Bacterial strains}

The study was conducted with a bacteriocinogenic Lactococcus lactis subsp. lactis strain (Lc. lactis DF04Mi) isolated from raw goat milk (Furtado et al., 2009). L. monocytogenes 711 (collection of University of São Paulo, Faculty of Pharmaceutical Sciences, Department of Food Science and Experimental Nutrition) and E. faecalis ATCC 19433 and Lactobacillus sakei ATCC 15521 (ATCC, Manassas, Virginia, USA) were used as co-aggregation partners. All strains were stored at $-80{ }^{\circ} \mathrm{C}$ in presence of $15 \%$ glycerol.

Auto-aggregation and co-aggregation with $L$. monocytogenes 711, E. faecalis ATCC 19433 and Lb. sakei ATCC 15521

The cells of a culture of Lc. lactis DF04Mi grown in MRS broth (Difco) for $24 \mathrm{~h}$ at $37^{\circ} \mathrm{C}$ were harvested by centrifugation $\left(7,000 \mathrm{x} \mathrm{g}, 10 \mathrm{~min}, 20^{\circ} \mathrm{C}\right)$, washed and resuspended in sterile saline $(0.85 \% \mathrm{NaCl}, \mathrm{w} / \mathrm{v})$. One $\mathrm{ml}$ of the cell suspension adjusted to an $\mathrm{OD}_{660 \mathrm{~nm}}=0.3$ was transferred to a $2 \mathrm{~mL}$ sterile plastic cuvette and the $\mathrm{OD}_{660 \mathrm{~mm}}$ recorded, using a spectrophotometer (Ultraspec 2000, Pharmacia Biotech). After 60 min $\mathrm{OD}_{660 \mathrm{~nm}}$ readings were performed in the supernatant, after centrifuging the cultures at $300 \mathrm{x} g$ for $2 \mathrm{~min}$ at $20^{\circ} \mathrm{C}$. Auto-aggregation was determined using the following equation (Todorov et al., 2008):

100

$\%$ Auto-aggregation $=\left[\left(\mathrm{OD}_{0 \min }-\mathrm{OD}_{60 \min }\right) / \mathrm{OD}_{0 \min }\right] \mathrm{x}$

$\mathrm{OD}_{0 \min }$ and $\mathrm{OD}_{60 \mathrm{~min}}$ refer to the initial $\mathrm{OD}$ and the $\mathrm{OD}$ determined after $60 \mathrm{~min}$, respectively.

For evaluation of co-aggregation strains Lc. lactis DF04Mi, E. faecalis ATCC 19433 and Lb. sakei ATCC 15521 were grown in $10 \mathrm{~mL}$ MRS at $30{ }^{\circ} \mathrm{C}$ and $L$. monocytogenes 711 in $10 \mathrm{~mL} \mathrm{BHI}$ at $37^{\circ} \mathrm{C}$. Cells were harvested after $24 \mathrm{~h}\left(7,000 \times \mathrm{g}, 10 \mathrm{~min}, 20^{\circ} \mathrm{C}\right)$, washed and re-suspended in sterile saline $(0.85 \% \mathrm{NaCl})$. One $\mathrm{ml}$ of the cell suspension of Lc. lactis DF04Mi (adjusted to an $\left.\mathrm{OD}_{660 \mathrm{~nm}}=0.3\right)$ and $1 \mathrm{~mL}$ of co-aggregation partner (adjusted to an $\mathrm{OD}_{660 \mathrm{~nm}}=0.3$ ) were mixed and transferred to a $2 \mathrm{~mL}$ sterile plastic cuvette and the $\mathrm{OD}_{660 \mathrm{~nm}}$ recorded using a spectrophotometer. $\mathrm{OD}_{660 \mathrm{~nm}}$ readings were performed in the supernatant after $60 \mathrm{~min}$ and after centrifuging the suspension at $300 \mathrm{x} g$ for $2 \mathrm{~min}$ at $20^{\circ} \mathrm{C}$. Co-aggregation was calculated using the following equation (Todorov et al., 2008):

100

$$
\% \text { Co-aggregation }=\left[\left(\mathrm{OD}_{0 \min }-\mathrm{OD}_{60 \mathrm{~min}}\right) / \mathrm{OD}_{0 \min }\right] \mathrm{x}
$$

$\mathrm{OD}_{0 \min }$ and $\mathrm{OD}_{60 \mathrm{~min}}$ refer to the $\mathrm{OD}$ determined immediately after mixing the cultures and the OD determined after $60 \mathrm{~min}$, respectively. Experiments were conducted in triplicates on two separate occasions.

\section{Effect of $\mathrm{pH}$ and bile on growth}

Lc. lactis DF04Mi was grown in MRS broth (Difco) adjusted to $\mathrm{pH} 3.0,4.0,5.0,6.0,7.0,9.0,11.0$ and 13.0 by adding $1 \mathrm{M} \mathrm{HCl}$ or $1 \mathrm{M} \mathrm{NaOH}$ before autoclaving. If needed, $\mathrm{pH}$ was re-adjusted after sterilization by adding sterile $1 \mathrm{M} \mathrm{HCl}$ or $1 \mathrm{M} \mathrm{NaOH}$. The strain was also grown in MRS broth containing $0.2 \%, 0.4 \%, 0.6 \%, 0.8 \%, 1.0 \%$, $2.0 \%$ and $3.0 \%(\mathrm{w} / \mathrm{v})$ oxbile (Sigma). All tests were conducted in sterile flat-bottom 96-well microtiter plates (TPP, Switzerland). Each well was filled with $180 \mu \mathrm{L}$ of the medium and inoculated with $20 \mu \mathrm{L}$ of cultures of Lc. lactis DF04Mi activated in MRS broth (Difco) at $37^{\circ} \mathrm{C}$ until presenting $\mathrm{OD}_{600 \mathrm{~mm}}=0.2$. Growth of Lc. lactis $\mathrm{DF} 04 \mathrm{Mi}$ in the tested conditions was monitored through determination of $\mathrm{OD}_{600 \mathrm{~nm}}$ every hour for $12 \mathrm{~h}$, using a microtiter plate reader (Versa-max, Sunnyvale, CA, USA). Cultures grown in non-modified MRS broth served as control. Experiments were done in triplicate.

\section{Determination of cell surface hydrophobicity in $L c$. lactis DF04Mi}

The test for bacterial adhesion to hydrocarbons (BATH), described by Doyle and Rosenberg (1995) with some modification (Todorov et al., 2008), was used. Lc. lactic DF04Mi was grown in MRS broth (Difco) at $37^{\circ} \mathrm{C}$ for $18 \mathrm{~h}$. Cells were harvested $\left(6,700 \mathrm{~g}, 4^{\circ} \mathrm{C}, 6 \mathrm{~min}\right)$, washed twice with sterile saline solution $(0.85 \% \mathrm{NaCl})$, resuspended in the same solution and the optical density $\left(\mathrm{OD}_{580 \mathrm{~nm}}\right)$ was determined. An aliquot e of $1.5 \mathrm{~mL}$ cell suspension was added to $1.5 \mathrm{~mL} n$-hexadecane (Sigma) and vortexed for $2 \mathrm{~min}$. The phases were allowed to separate for $30 \mathrm{~min}$ at room temperature. One $\mathrm{ml}$ of the watery phase was removed and the optical density $\left(\mathrm{OD}_{580 \mathrm{~nm}}\right)$ determined. The experiment was repeated and the average optical density value determined. The percentage of hydrophobicity was calculated as follows: 
$\%$ hydrophobicity $=\left[\left(\mathrm{OD}_{580}\right.\right.$ reading $1-\mathrm{OD}_{580}$ reading 2) / $\mathrm{OD}_{580}$ reading 1] x 100 .

Experiments with all strains were conducted in triplicate.

\section{Resistance to drugs and antibiotics}

Lc. lactis DF04Mi was tested for resistance to several drugs used in human and animal therapy, purchased in local drugstores (Sao Paulo, SP, Brazil) and solubilized in sterile water to achieve the desired concentration listed in Table 1. An overnight culture of Lc. lactis DF04Mi in MRS broth (Difco) was mixed with MRS soft agar (1.0\%, w/v, Difco) in order to achieve a population of $10^{6} \mathrm{cfu} / \mathrm{mL}$ and transferred to empty petri plates. After solidification of the agar $10 \mu \mathrm{L}$ of each tested drug were spotted onto the surface. The plates were incubated at $37^{\circ} \mathrm{C}$ for $24 \mathrm{~h}$, examined for the presence of inhibition zones around the spotted drug, and those presenting inhibition zones larger than $2 \mathrm{~mm}$ diameter were subjected to the determination of the minimal inhibition concentration (MIC). For this test, serial twofold dilutions of the drug were prepared in sterile water and $10 \mu \mathrm{L}$ were spotted onto the surface of MRS soft agar plates, previously inoculated with strain Lc. lactis DF04Mi (approx. $10^{6} \mathrm{cfu} / \mathrm{mL}$ ). The plates were incubated for $24 \mathrm{~h}$ at $37^{\circ} \mathrm{C}$ and examined for the presence of inhibition zones around the spots. The MIC corresponded to the highest dilution that resulted in inhibition halos of at least $2 \mathrm{~mm}$ diameter. In a similar experimental approach, susceptibility of strain Lc. lactis DF04Mi to antibiotics listed in Table 2 was tested by the disk diffusion test, using antibiotic disks from CEFAR (Sao Paulo, Brazil). The inhibitory effect of the antibiotics was expressed in millimeters of the inhibition zones.

\section{Results and Discussion}

Bacteriocin produced by Lc. lactis DF04Mi presented a large spectrum of activity, inhibiting the growth of many food spoilage bacteria and foodborne pathogens. Similar results were recorded for the cell free supernatant and for the semi-purified bacteriocin. It is important to emphasize the bioactivity against $L$. monocytogenes, a foodborne pathogen of increasing importance. Antimicrobial activity against Gram-negative bacteria is also a relevant characteristic that was previously detected in other microorganisms including bacteriocins produced by Lc. lactis DF04Mi (Furtado et al., 2009).

Auto-aggregation of Lc. lactis DF04Mi was low (12.2\%) (Figure 1). Co-aggregation of Lc. lactis DF04Mi with the pathogens L. monocytogenes 711 and E. faecalis ATCC 19443 was $30.0 \%$ and $24.3 \%$, respectively, which are lower values than for $L b$. sakei ATCC 15521, a nonpathogen. The low levels of auto-aggregation and coaggregation with pathogens may play an important role in preventing the formation of biofilms, and in this way eliminating the pathogens from the gastrointestinal tract.

Good growth of Lc. lactis DF04Mi was recorded in MRS broth (Difco) when the initial $\mathrm{pH}$ was $6.0,7.0$ or 9.0 (Figure 2). Similar results were reported for Lc. lactis subsp. lactis HV219 (Todorov et al., 2007). In another study, growth of several strains of $L b$. plantarum, $L b$. rhamnosus, Lb. pentosus and Lb. paracase $i$ was suppressed at $\mathrm{pH} 3.0$ and 4.0, while variable results were recorded in medium with an initial $\mathrm{pH}$ of 11.0 and 13.0 , with poor growth recorded for strains $L b$. paracasei ST242BZ and ST284BZ, Lb. rhamnosus ST462BZ, Lb. plantarum ST664BZ and Lb. pentosus ST712BZ at pH 13.0 (Todorov et al., 2008).

Lc. lactis DF04Mi grew well in the absence of oxbile, or when the concentration was below $3.0 \%$ (Figure 2). The bacteriocinogenic Lc. lactis HV219 strain was less tolerant to bile salts, as the growth of it was inhibited by concentrations of oxbile above $0.3 \%$ (Todorov et al., 2007).

Other studies have also reported similar effects of oxbile and $\mathrm{pH}$ for different strains of Lc. lactis, such as $L b$. plantarum 423, Lb. salivarius 241 and Lb. curvatus DF38 (Brink et al., 2006). Haller et al. (2001) reported variable results for different strains of $L b$. plantarum when exposed to $\mathrm{HCl}(\mathrm{pH} 2.0$ ) and bile salts, and as many as $10 \%$ of $L b$. plantarum cells, but less than $0.001 \%$ of $L b$. sakei and $L b$. paracasei cells survived these conditions. Although these assays cannot predict the behavior of the microorganism in the human body, the results are valuable in selecting Lactococcus spp. for probiotic applications, as resistance to low $\mathrm{pH}$ and high concentrations of bile salts is important for growth and survival of bacteria in the intestinal tract (Havenaar et al., 1992; Carvalho et al., 2009).

It has been suggested that there is a possible correlation between surface hydrophobicity of probiotic strains and the ability to adhere to the intestinal mucosa (Wadstrom et al., 1987). Cell surface hydrophobicity defines a non-specific interaction between microbial and host cells. The initial interaction may be weak, is often reversible and precedes subsequent adhesion processes mediated by more specific mechanisms involving cell-surface proteins and lipoteichoic acids (Granato et al., 1999; Rojas et al., 2002; Roos and Jonsson, 2002). Bacterial cells with a high hydrophobicity usually form strong interactions with mucosal cells. Hydrophobicity values of $52.4 \%$ were recorded for Lc. lactis DF04Mi. Higher hydrophobicity values of $75 \%-80 \%$ were recorded for strains $L$ b. rhamnosus ST461BZ, Lb. rhamnosus ST462BZ and Lb. plantarum ST664BZ and these values were higher than those reported for $L$ b. rhamnosus GG, well known commercial probiotic (55\%) (Todorov et al., 2008). Hydrophobicity varies among genetically close related species and even among strains of the same species (Schar-Zammaretti and Ubbink, 2003). Some strains with a high cell surface hydrophobicity were not able to properly adhere to Caco-2 and HT-29 cells 
Table 1 - Effect of drugs on growth of Lactococcus lactis subsp lactis DF04Mi in MRS agar, presented as diameter of inhibition zones and Minimal Inhibitory Concentration (MIC).

\begin{tabular}{|c|c|c|c|c|}
\hline $\begin{array}{l}\text { Brazilian commercial } \\
\text { name }\end{array}$ & $\begin{array}{l}\text { Concentration } \\
(\mathrm{mg} / \mathrm{mL})\end{array}$ & Active substance & Medicament class & $\begin{array}{l}\text { Inhibition zone }(\mathrm{mm}) \\
\text { [MIC }(\mathrm{mg} / \mathrm{mL})]\end{array}$ \\
\hline AAS & 20 & Acetylsalicylic acid & Analgesic / Antipyretic & - \\
\hline Amoxil & 100 & Amoxicillin & $\beta$-Lactam antibiotic (Penicilin) & $40[<0.2]$ \\
\hline Antak & 30 & Ranitidine hydrochloride & $\begin{array}{l}\text { Histamine H2-receptor antago- } \\
\text { nist (proton pump inhibitor) }\end{array}$ & - \\
\hline Arotin & 4 & Paroxetine & $\begin{array}{l}\text { selective serotonin reuptake in- } \\
\text { hibitor (SSRI) antidepressant }\end{array}$ & - \\
\hline Aspirina & 100 & Acetylsalicylic acid & Analgesic / Antipyretic & - \\
\hline Atlansil & 40 & Amiodarone & Antiarrhythmic & $12[1.25]$ \\
\hline Cataflam & 10 & Diclofenac potassium & $\begin{array}{l}\text { Non-steroidal } \\
\text { anti-inflammatory drug } \\
\text { (NSAID) }\end{array}$ & $20[2.5]$ \\
\hline Celebra & 40 & Celecoxib & NSAID & - \\
\hline Clorana & 5 & Hydrochlorothiazide & Diuretic & - \\
\hline Coristina $\mathrm{R}$ & & $\begin{array}{l}\text { Acetylsalicylic acid, Pheniramine } \\
\text { maleate, Phenylephrine hydrochloride, Cafein }\end{array}$ & $\begin{array}{l}\text { Analgesic / Antipyretic / Anti- } \\
\text { histaminic / Decongestant. }\end{array}$ & - \\
\hline Diclofenaco* & 10 & Diclofenac potassium & NSAID & $18[0.16]$ \\
\hline Diclofenaco* & 10 & Diclofenac potassium & NSAID & $14[0.32]$ \\
\hline Dorflex & 10 & $\begin{array}{l}\text { Orphenadrine citrate, Metamizole so- } \\
\text { dium, Cafein }\end{array}$ & Analgesic & - \\
\hline Doxuran & 0.8 & Doxazosin & $\begin{array}{l}\text { Antihypertensive / Treatment of } \\
\text { prostatic hyperplasia }\end{array}$ & - \\
\hline Dramin & 20 & Dimenhydrinate & Antiemetic & - \\
\hline Fenergan & 5 & Promethazine hydrochloride & Antihistaminic & - \\
\hline Fluimucil & 8 & Acetylcysteine & Mucolitic agent & - \\
\hline Flutec & 30 & Fluconazole & Antifungal & - \\
\hline Higroton & 10 & Chlorthalidone & Thiazide diuretic & \\
\hline Omeprazole & 4 & Omeprazole & Proton pump inhibitor & - \\
\hline Neosaldina & 60 & $\begin{array}{l}\text { Metamizole sodium, isometheptene } \\
\text { mucate, cafein }\end{array}$ & Analgesic & - \\
\hline Nimesulida & 20 & Nimesulide & NSAID & - \\
\hline Nisulid & 20 & Nimesulide & NSAID & - \\
\hline Redulip & 3 & Sibutramine hydrochloride monohydrate & Anorexiant / Sympathomimetic & - \\
\hline Seki & 3.54 & Cloperastine & $\begin{array}{l}\text { Antitussives (central and } \\
\text { periferic mode of action) }\end{array}$ & - \\
\hline Spidufen & 120 & Ibuprofen arginine & NSAID & $20[7.5]$ \\
\hline Superhist & 80 & $\begin{array}{l}\text { Acetylsalicylic acid, Pheniramine } \\
\text { maleate, Phenylephrine hydrochloride }\end{array}$ & $\begin{array}{l}\text { Analgesic / Antipyretic / Anti- } \\
\text { histaminic / Decongestant }\end{array}$ & - \\
\hline Tylenol & 150 & Paracetamol & Analgesic / Antipyretic & - \\
\hline Tylex & 6 & Paracetamol, Codein & Analgesic & - \\
\hline Urotrobel & 80 & Norfloxacin & Antibiotic & $10[2.5]$ \\
\hline Yasmin & 0.6 & Ethinylestradiol, drospirenone & Contraceptive & - \\
\hline Zestril & 4 & Lisinopril & $\begin{array}{l}\text { Antihypertensive (Angioten- } \\
\text { sin-converting enzyme (ACE) } \\
\text { inhibitor) }\end{array}$ & - \\
\hline Zocor & 2 & Simvastatin & Hypolipidemic & - \\
\hline Zyrtec & 2 & Cetirizine hydrochloride & Antihistaminic & - \\
\hline
\end{tabular}

*Produced by two different companies. - = no inhibition. 
Table 2 - Effect of antibiotics on the growth of Lactococcus lactis subsp lactis DF04Mi, presented as diameter of the inhibition zone.

\begin{tabular}{|c|c|c|}
\hline Antibiotic $(\mu \mathrm{g} /$ disk $)$ & Classification (mode of action) & Inhibition zone $(\mathrm{mm})$ \\
\hline Amicacin $(30)$ & Aminoglycoside (inhibits protein synthesis) & 13 \\
\hline Ampicilin (10) & Penicillin / $\beta$-Lactam (interferes with bacteria cell wall synthesis) & 30 \\
\hline Bacitracin (10) & Cyclic polypeptide (inhibits bacteria cell wall synthesis) & 21 \\
\hline Cefazolin (30) & $1^{\text {st }}$ generation cephalosporin / $\beta$-Lactam (interferes with bacteria cell wall synthesis) & 24 \\
\hline Cefepime (30) & $4^{\text {th }}$ generation cephalosporin / $\beta$-Lactam (interferes with bacteria cell wall synthesis) & 34 \\
\hline Cefotaxim (30) & $2^{\text {nd }}$ generation cephalosporin / $\beta$-Lactam (interferes with bacteria cell wall synthesis) & 33 \\
\hline Ceftazidim (30) & $3^{\text {th }}$ generation cephalosporin / $\beta$-Lactam (interferes with bacteria cell wall synthesis) & 23 \\
\hline Ceftriaxon (30) & $3^{\text {th }}$ generation cephalosporin / $\beta$-Lactam (interferes with bacteria cell wall synthesis) & 30 \\
\hline Cefuroxim (30) & $\beta$-Lactam (interferes with bacteria cell wall synthesis) & 30 \\
\hline Ciprofloxacin (5) & Fluoroquinolone (inhibits the bacterial topoisomerase II) & 18 \\
\hline Clindamicin (2) & Licosamide (inhibits protein synthesis) & 25 \\
\hline Cloranfenicol (30) & Chloramphenicol (prevents peptide bond formation - inhibits protein synthesis) & 28 \\
\hline Erytromicin (15) & Macrolide (inhibits protein synthesis) & 28 \\
\hline Furazolidon (10) & Antibiotic / antiparasitic & 21 \\
\hline Gentamicin (10) & Aminoglycoside (inhibits protein synthesis) & 15 \\
\hline Imipenem (10) & Carbapenem / $\beta$-Lactam (interferes with bacteria cell wall synthesis) & 32 \\
\hline Kanamicin (30) & Aminoglycoside (inhibits protein synthesis) & 17 \\
\hline Metronidazol (50) & Nitroimidazole antibiotic (acts on DNA of microorganisms ameba, and protozoa) & 0 \\
\hline Nalidixic acid (30) & Syntetic quinolone antibiotic (acts on DNA gyrase) & 0 \\
\hline Neomicin (30) & Aminoglycoside (inhibits protein synthesis) & 15 \\
\hline Nitrofurantoin (300) & Nitrofuran derivative (nucleic acid inhibitor) & 22 \\
\hline Ofloxacin (5) & Licosamide (inhibits protein synthesis) & 22 \\
\hline Oxacilin (1) & $\beta$-Lactam (interferes with bacteria cell wall synthesis) & 15 \\
\hline Penicillin G (10) & Penicilin / $\beta$-Lactam (interferes with bacteria cell wall synthesis) & 30 \\
\hline Rifampicin (30) & $\begin{array}{c}\text { Semisynthetic compound derived from Amycolatopsis rifamycinica (inhibits DNA-dependent RNA } \\
\text { polymerase) }\end{array}$ & 17 \\
\hline Rifampicin (5) & $\begin{array}{c}\text { Semisynthetic compound derived from Amycolatopsis rifamycinica (inhibits DNA-dependent RNA } \\
\text { polymerase) }\end{array}$ & 16 \\
\hline Streptomicin (10) & Aminoglycoside (inhibits protein synthesis) & 20 \\
\hline Tetraciclin (30) & Tetraciclin (inhibits protein synthesis) & 35 \\
\hline Tobramicin (10) & Aminoglycoside (inhibits protein synthesis) & 15 \\
\hline Trimetoprim (5) & Trimetoprim (inhibts folate syntesis) & 0 \\
\hline Vancomicin (30) & Glycopeptide (inhibits bacteria cell wall synthesis) & 21 \\
\hline
\end{tabular}

(Todorov et al., 2008). Strain Lb. pentosus ST712BZ, characterised with a relatively low hydrophobicity $(38 \%)$ adhered to HT-29 cells at $63 \%$. Only $32 \%$ adherence was recorded for Lb. rhamnosus GG (Todorov et al., 2008). Although hydrophobicity may assist in adhesion, it is not a prerequisite for strong adherence to human intestinal cells.

The effect of drugs on the survival of probiotic strains is important for patients being treated for chronic diseases and taking probiotics. As shown in Table 1, Lc. lactis DF04Mi was inhibited by antiarrhrythmic drugs containing amiodarone, by non-steroidal anti-inflammatory drugs containing potassium diclofenac or ibuprofen arginine, and by the two tested antibiotics (amoxyl and urotrobel). The interference of anti-inflammatory drugs containing diclofenac on the viability of $L A B$ detected in this study was also reported for other bacteriocinogenic LAB such as $L b$. plantarum ST8KF and ST341LD, E. faecium ST311LD and Le. mesenteroides subsp. mesenteroides ST33LD (Todorov and Dicks, 2008), Lc. lactis subsp. lactis HV219 (Todorov et al., 2007), Lb. casei Shirota and Lb. casei LC01 (Carvalho et al., 2009) and Lb. casei Shirota (Botes et al., 2008).

It should be pointed out that the activity of these medicaments against potential probiotic bacteria depends on the amount of the active compound that reaches the GIT, and that the correct evaluation of possible interactions be- 


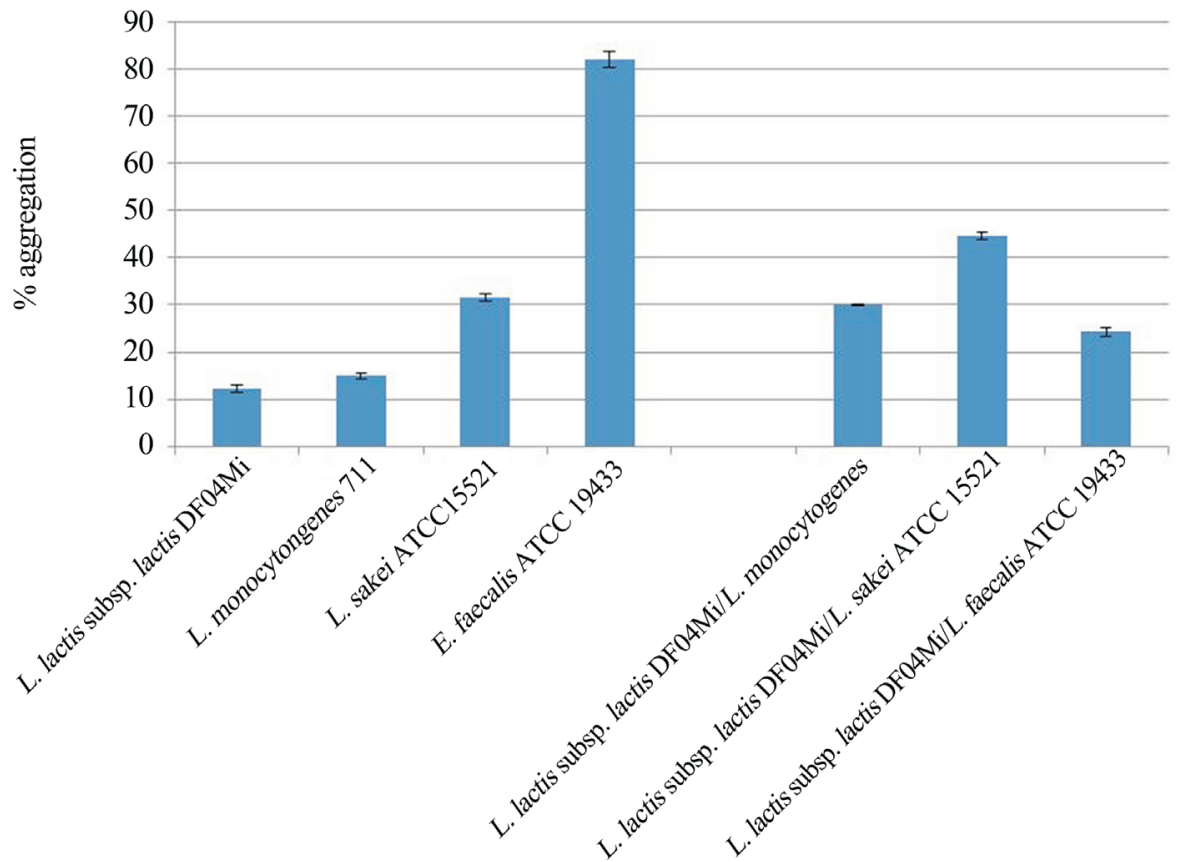

Figure 1 - Auto-aggregation of Lactococcus lactis subsp. lactis DF04Mi, Listeria monocytogenes 711, Lactobacillus sakei ATCC 15521 and Enterococcus faecalis ATCC 19433 and co-aggregation of Lactococcus lactis subsp. lactis DF04Mi with Listeria monocytogenes 711, Lactobacillus sakei ATCC 15521 or Enterococcus faecalis ATCC 19433.
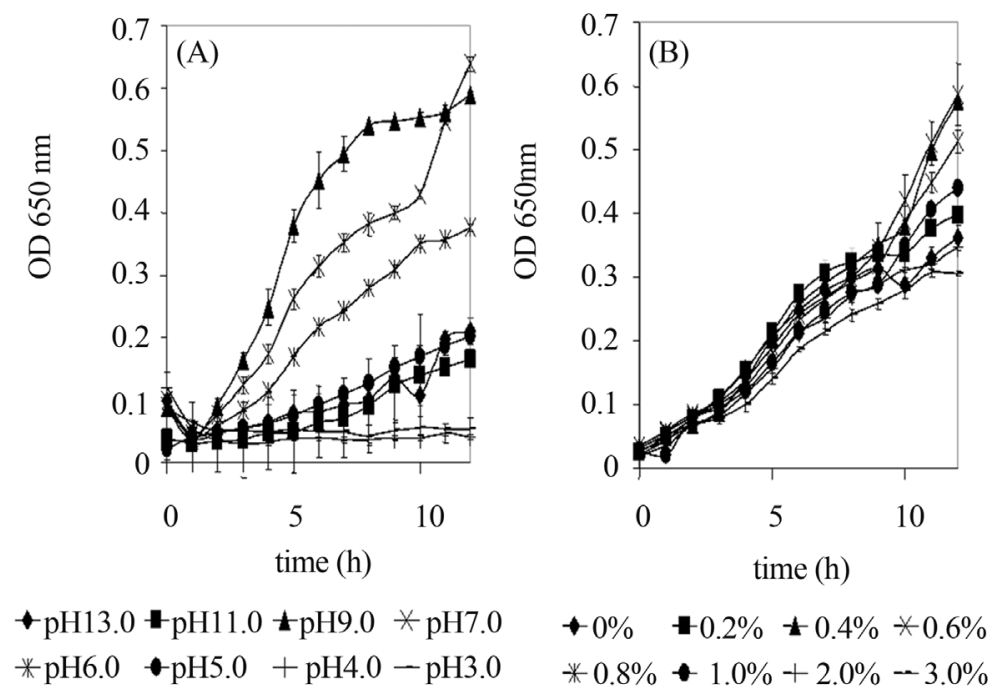

Figure 2 - Growth of Lactococcus lactis subsp. lactis DF04Mi in MRS containing increasing concentrations (0 to 3\%) of oxbile (B) and at different pH (3 to 13) (A).

tween them depends on the determination of MIC of these medicaments (Todorov et al., 2007, 2008). Due to their long-term application, drugs may accumulate in the GIT and MIC be reached, affecting the viability of the probiotic cultures.

The non-steroidal anti-inflammatory drugs were the medicaments that affected Lc. lactis DF04Mi more significantly and potassium diclofenac presented MIC of 0.16 $\mathrm{mg} / \mathrm{mL}$ and spidufen of $7.5 \mathrm{mg} / \mathrm{mL}$. Considering that the recommended daily doses of these two drugs are 100-150 $\mathrm{mg}$ and $600 \mathrm{mg}$ respectively, they will hardly affect the survival of Lc. lactis DF04Mi. Similar results were reported in other studies run with other probiotic LAB and gastrointestinal tract related bacteria (Botes et al., 2008; Todorov and Dicks, 2008; Carvalho et al., 2009; Todorov et al., 2007, 2008).

Except for metronidasole, nalidixic acid and trimetoprim, all the antibiotics tested (Table 2) in this study inhibited the growth of Lc. lactis DF04Mi to some extent. However, it is important to point out that nalidixic acid is an 
antibiotic mostly active against Gram-negative bacteria. Resistance of LAB to antibiotics is a controversial subject. It is important to keep in mind that antibiotic-resistant probiotic LAB may be responsible for horizontal transfer of resistance genes to other bacteria present in the human GIT (Dicks et al., 2011). Resistance may be inherent to a bacterial genus or species, but may also be acquired through exchange of genetic material, mutations or incorporation of new genes (Ammor et al., 2007). Teuber (1999) and Salyers et al. (2004) suggested that starter cultures and probiotics may serve as vectors in the transfer of antibiotic resistant genes. Such transfer was documented in other bacterial groups by Levy and Marshall (2004) and Salyers et al. (2004).

Results gathered in this study indicate the potential application of Lc. lactis DF04Mi isolated from goat milk for manufacturing of novel and functional goat milk products, with increased safety as it is capable to produce bacteriocins with antilisterial activity and presents several features that suggest probiotic activity.

\section{Acknowledgments}

This research was supported by grants from FAPESP (Sao Paulo, SP), CAPES (Brasilia, DF) and CNPq (Brasilia, DF), Brazil.

\section{References}

Ammor MS, Flóres AB, Mayo B (2007) Antibiotic resistance in not-enterococcal lactic acid bacteria and bifidobacteria. Food Microbiol 24:559-570.

Bertazzoni-Minelli E, Benini A, Marzotto M, Sbarbati A, Ruzzenente O, Ferrario R, Hendriks H, Dellaglio F (2004) Assessment of novel probiotic Lactobacillus casei strains for the production of functional foods. Int Dairy J 14:723-736.

Botes M, Van Reenen CA, Dicks LMT (2008) Evaluation of Enterococcus mundtii ST4SA and Lactobacillus plantarum 423 as probiotics by using a gastro-intestinal model with infant milk formulations as substrate. Int J Food Microbiol 128:362-370.

Brink M, Todorov SD, Martin JH, Senekal M, Dicks LMT (2006) The effect of prebiotics on production of antimicrobial compounds, resistance to growth at low $\mathrm{pH}$ and in the presence of bile, and adhesion of probiotic cells to intestinal mucus. $\mathrm{J}$ Appl Microbiol 100:813-820.

Carvalho KG, Kruger MF, Furtado DN, Todorov SD, Franco BDGM (2009) Evaluation of the role of environmental factors in the human gastrointestinal tract on the behaviour of probiotic cultures Lactobacillus casei Shirota and Lactobacillus casei LC01 by the use of a semi-dynamic in vitro model. Ann Microbiol 59:439-445.

Chan ES, Zhang Z (2005) Bioencapsulation by compression coating of probiotic bacteria for their protection in an acidic medium. Process Biochem 40:3346-3351.

Dicks LMT, Todorov SD, Franco BDGM (2011) Current status of antibiotic resistance in lactic acid bacteria, pp. 379-425, In: Bonilla AR, Muniz KP (Eds.) Antibiotic Resistance: Causes and Risk Factors, Mechanisms and Alternatives. Pharmacol- ogy - Research, Safety Testing and Regulation. Nova Publisher, New York.

Doyle RJ, Rosenberg M (1995) Measurement of microbial adhesion to hydrophobic substrates. Meth Enzymol 253:542550.

Furtado DN, Todorov SD, Chiarini E, Destro MT, Landgraf M, Franco BDGM (2009) Goat milk and cheeses may be a good source for antilisterial bacteriocin-producing lactic acid bacteria. Biotechnol Biotechnol Eq 23:775-778.

Galdeano C, de Moreno A, Vinderola G, Bibas Bonet ME, Perdigón G (2007) A proposal model: mechanisms of immunomodulation induced by probiotic bacteria. Review. Clin Vacc Immunol 14:485-492.

Gomes AMP, Xavier MF (1999) Bifidobacterium spp. and Lactobacillus acidophilus: biological, biochemical, technological and therapeutical properties relevant for use as probiotics. Trends Food Sci Technol 10:139-157.

Granato D, Perotti F, Masserey I, Rouvet M, Golliard M, Servin A, Brassart D (1999) Cell surface-associated lipoteichoic acid acts as an adhesion factor for attachment of Lactobacillus johnsonii La1 to human enterocyte-like Caco-2 cells. Appl. Environ. Microbiol. 65:1071-1077.

Haller D, Colbus H, Ganzle MG, Scherenbacher P, Bode C, Hammes WP (2001) Metabolic and functional properties of lactic acid bacteria in the gastro-intestinal ecosystem: A comparative in vitro study between bacteria of intestinal and fermented food origin. Syst Appl Microbiol 24:218-226.

Havenaar R, Ten Brink B, Huis in't Veld JHC (1992) Selection of strains for probiotic use. In Probiotics: The Scientific Basis ed. Fuller R. London: Chapman and Hall.

Kailasapathy K, Chin J (2000) Survival and therapeutic potential of probiotic organisms with reference to Lactobacillus acidophilus and Bifidobacteria spp. Immunol Cell Biol 78:80-88.

Kleerebezem M, Boekhorst J, van Kranenburg R, Molenaar D, Kuipers OP, Leer R, Tarchini R, Peters SA, Sandbrink HM, Fiers MWEJ, Stiekema W, Lankhorst RMK, Bron PA, Hoffer SM, Groot MNN, Kerkhoven R, de Vries M, Ursing B, de Vos WM, Siezen RJ (2003) Competitive genome sequence of Lactobacillus plantarum WCFS1. Proceed Nat Acad Sci USA 100:1990-1995.

Levy SB, Marshall B (2004) Antibacterial resistance worldwide: causes, challenges and responses. Nat Med Rev 10:S122S129.

Oelschlaeger TA (2010) Mechanisms of probiotic actions - A review. Int J Med Microbiol 300:57-62.

Rojas M, Ascencio F, Conway PL (2002) Purification and characterization of a surface protein from Lactobacillus fermentum $104 \mathrm{R}$ that binds to porcine small intestinal mucus and gastric mucin. Appl Environ Microbiol 68:2330-2336.

Roos S, Jonsson H (2002) A high-molecular-mass cell-surface protein from Lactobacillus reuteri 1063 adheres to mucus components. Microbiol 148:2481-2489.

Salyers AA, Gupta A, Wang Y (2004) Human intestinal bacteria as reservoirs for antibiotic resistance genes. Trends Microbiol 12:412-416.

Schar-Zammaretti P, Ubbink J (2003) The cell wall of lactic acid bacteria: surface constituents and macromolecular conformations. Biophysics J 85:4076-4092.

Teuber M (1999) Spread of antibiotic resistance with food-borne pathogens. Cell Mol Life Sci 56:755-763. 
Todorov SD, Dicks LMT (2008) Evaluation of lactic acid bacteria from kefir, molasses and olive brine as possible probiotics based on physiological properties. Ann Microbiol 58:661670 .

Todorov SD, Botes M, Danova ST, Dicks LMT (2007) Probiotic properties of Lactococcus lactis subsp. lactis HV219, isolated from human vaginal secretions. J Applied Microbiol 103:629-639.

Todorov SD, Botes M, Guigas C, Schillinger U, Wiid I, Wachsman MB, Holzapfel WH, Dicks LMT (2008) Boza, a natural source of probiotic lactic acid bacteria. J Appl Microbiol 104:465-477.
Todorov SD, LeBlanc JG, Franco BDGM (2012) Evaluation of the probiotic potential and effect of encapsulation on survival for Lactobacillus plantarum ST16Pa isolated from papaya. World J Microbiol Biotechnol 28:973-984.

Wadström T, Andersson K, Sydow M, Axelsson L, Lindgren S, Gullmar B (1987) Surface properties of lactobacilli isolated from the small intestine of pigs. J Appl Bacteriol 62:513-520.

WHO (World Health Organization) (2002) Guidelines for the Evaluation of Probiotics in Food. Available at www.who.int/foodsafety/fs_management/en/probiotic_guidelines.pdf.

All the content of the journal, except where otherwise noted, is licensed under a Creative Commons License CC BY-NC. 